\title{
Do Economic Policy Uncertainty and Geopolitical Risk Lead to Environmental Degradation? Evidence from Emerging Economies
}

\author{
Muhammad Khalid Anser ${ }^{1}\left(\mathbb{D}\right.$, Qasim Raza Syed ${ }^{2}$, , Hooi Hooi Lean ${ }^{3, *(\mathbb{D} \text {, Andrew Adewale Alola }}{ }^{4,5}$ \\ and Munir Ahmad ${ }^{6}$ (D) \\ 1 School of Public Administration, Xi'an University of Architecture and Technology, Xi'an 710055, China; \\ khalidrao@xauat.edu.cn \\ 2 National Tariff Commission, Ministry of Commerce, Islamabad 44000, Pakistan; \\ qasimrazasyed.economics@gmail.com \\ 3 Economics Program, School of Social Sciences, Universiti Sains Malaysia, Penang 11800, Malaysia \\ 4 Department of Economics and Finance, Istanbul Gelisim University, Istanbul 34310, Turkey; \\ aadewale@gelisim.edu.tr \\ 5 Department of Financial Technologies, South Ural State University, 454080 Chelyabinsk, Russia \\ 6 School of Economics, Zhejiang University, Hangzhou 310000, China; munirahmad@zju.edu.cn \\ * Correspondence: hooilean@usm.my or learnmy@gmail.com
}

Citation: Anser, M.K.; Syed, Q.R.; Lean, H.H.; Alola, A.A.; Ahmad, M. Do Economic Policy Uncertainty and Geopolitical Risk Lead to Environmental Degradation? Evidence from Emerging Economies. Sustainability 2021, 13, 5866. https:// doi.org/10.3390/su13115866

Academic Editor: Elena Cristina Rada

Received: 8 April 2021

Accepted: 13 May 2021

Published: 23 May 2021

Publisher's Note: MDPI stays neutral with regard to jurisdictional claims in published maps and institutional affiliations.

Copyright: (c) 2021 by the authors. Licensee MDPI, Basel, Switzerland. This article is an open access article distributed under the terms and conditions of the Creative Commons Attribution (CC BY) license (https:// creativecommons.org/licenses/by/ $4.0 /)$.

\begin{abstract}
Since the turn of twenty first century, economic policy uncertainty (EPU) and geopolitical risk (GPR) have escalated across the globe. These two factors have both economic and environmental impacts. However, there exists dearth of literature that expounds the impact of EPU and GPR on environmental degradation. This study, therefore, probes the impact of EPU and GPR on ecological footprint (proxy for environmental degradation) in selected emerging economies. Cross-sectional dependence test, slope heterogeneity test, Westerlund co-integration test, fully modified least ordinary least square estimator, dynamic OLS estimator, and augmented mean group estimator are employed to conduct the robust analyses. The findings reveal that EPU and non-renewable energy consumption escalate ecological footprint, whereas GPR and renewable energy plunge ecological footprint. In addition, findings from the causality test reveal both uni-directional and bi-directional causality between a few variables. Based on the findings, we deduce several policy implications to accomplish the sustainable development goals in emerging economies.
\end{abstract}

Keywords: ecological footprint; economic policy uncertainty; geopolitical risk; renewable energy consumption; non-renewable energy

\section{Introduction}

Economic policy uncertainty (EPU) could be defined as ambiguity and/or vagueness in economic policies, and it has been escalating since the turn of twenty first century. The recent events, e.g., financial crisis, Brexit, US-China trade war, and COVID-19 pandemic have surged the EPU worldwide. According to the country reports of the International Monetary Fund (IMF), EPU is among the leading factors responsible for sluggish economic growth. In addition to this, there exists profusion of studies that expound the economic impacts of EPU. For instance, several studies report that EPU effects economic growth [1,2], energy prices [3], stock market [4], and investment [5], etc. Hence, it could be concluded that EPU is an indispensable factor that has profound impact on economic indicators.

In addition to its economic impacts, EPU might have environmental impacts as well. EPU can plunge economic growth and energy consumption, which in turn ameliorates environmental quality. Also, EPU can impede renewable energy, R\&D, and innovation. These aforementioned factors ultimately cause an upsurge in environmental degradation. Hence, EPU can either improve or mitigate environmental degradation. 
Recently, one of the studies on the relationship between EPU and environmental quality proposes two channels that relate EPU with environmental degradation: (1) consumption effect; and (2) investment effect [6]. According to consumption effect, EPU mitigates the use of energy consumption and pollution-intensive commodities. As a result, environmental degradation will be mitigated. However, investment effect expounds that EPU impedes the investment in renewable energy and R\& D, which ultimately leads to environmental degradation. There exist a few research outlets that explore the impact of EPU on environmental degradation. Regarding the relationship between EPU and environment, one strand of literature notes that EPU upsurges the environmental degradation [6-9], whereas second strand of literature reports that EPU plunges environmental degradation [10-12]. Besides, there exists a study which highlights that EPU does not affect environment [13]. The contrasting findings of the prior literature call for the further investigation of the impact of EPU on environmental degradation.

Parallel to this, geopolitical risk (i.e., risk related to terrorism, war, militarization, and conflicts within \& between countries) has also been surging over the last few decades. The events, e.g., $9 / 11$ attack, Bombay attack, US-Iraq war, and China-India conflicts are the key episodes of geopolitical risk (GPR) over the last few decades. It has also been noticed that GPR adversely affects businesses, investment, and other economic activities. There exists a line of research that notes the economic effects of GPR. For instance, a several studies highlight that GPR effects economic growth and tourism [14], energy consumption [15], financial markets [16], and research and development $[17,18]$.

Contrary to its economic impacts, GPR may have environmental impacts as well. We propose two channels/effects through which GPR could affect the environment. The first channel is "mitigating effect", which argues that GPR plunges economic growth and energy consumption, and these factors (i.e., economic growth and energy consumption) impede environmental degradation. the second channel is an "escalating effect", which proposes that GPR mitigates R\&D, innovations, and renewable energy, which in turn surge environmental degradation. On the basis of this, we can report that GPR can either increase or decrease environmental degradation. Therefore, it is imperative for the researchers to explore the net impact of GPR on environmental degradation. In the prior literature regarding the impact of GPR on environment, there exists contrasting conclusion $[19,20]$ which propels researchers to further investigate this issue.

To complement the above backdrop, the objective of this study is to explore the impact of EPU and GPR on environmental degradation in Brazil, Russia, Mexico, Colombia, and China (BRMCC) from 1995 to 2015. This study will provide insightful information to these countries in a sense that the policy makers could devise appropriate policies to curb environmental degradation and accomplish sustainable development goals. BRMCC are a set of emerging countries which produced $22.07 \%$ of global GDP, and almost $25 \%$ of world population belongs to these countries (https:/ / www.worldometers.info, accessed on 22 May 2021). Moreover, BRMCC countries contribute almost $36.76 \%$ to world energy consumption. Last but not least, BRMCC countries produce $30.90 \%$ of the global ecological footprint (EF). Parallel to this, BRMCC countries are the economic and political powers of the new era. These countries have geopolitical tensions with each other, and with rest of the world.

More specifically, after the global financial crisis, Brazil also faced a severe financial crisis during 2013-2016 that raised its EPU. In addition, the protests and impeachments in Brazil aggravated the uncertainty. The significant fluctuations in the currency of Brazil are responsible for a high spike of EPU. It is worth to mention that Brazil also has geopolitical tensions. For instance, Brazil and Uruguay have critical territorial issues while Brazil and Colombia have disputes due to smuggling. Additionally, several periods of military government have surged the GPR in Brazil. According to the Brazilian Federal Police, seven terrorist groups are actively operating in Brazil, which also contributes to a higher GPR.

Being an oil-dependent economy, the EPU of Russia remains high due to the repeated oil price fluctuations. The economic crisis in 1998 also surged its EPU. Furthermore, the 
15 economic, 12 financial and 22 corporate sanctions that were imposed on Russia by the US and European Union pushed up its EPU and GPR. The Russia-Ukraine conflict is one of the prime sources of high GPR in Russia. The Moscow theater hostage crisis in 2002, Moscow school hostage event in 2004, Moscow market bombing in 2006, Moscow suicide bombing incident in 2010, airport suicide bombing in 2013, and the incident of Metro-jet Flight 9268 in 2015 are examples of geopolitical unrest in Russia.

Being the 6th largest oil producer, the EPU in Mexico remains high due to oil price fluctuations. Mexico has faced several economic crises which escalated its EPU. For instance, the Peso crisis in 1994 that occurred due to the devaluation of its currency and capital flight had adverse effects on economy and contributed to high EPU. The global financial crisis in 2008 exerted an adverse impact on the economy of Mexico, which in turn aggravated its EPU. Additionally, Mexico and the US have geopolitical tensions due to drug smuggling and illegal migration.

Likewise, Colombia confronted economic crises during the late 1990s and early 2000s. As a result, EPU in Colombia approached its peak. Apart from this, oil price fluctuations raised its EPU because the Colombian economy heavily depends on oil. Additionally, several terrorist groups operating in Colombia are responsible for the deaths and displacement of thousands of people. Operation Traira, the Mexican drug war, operation Atalanta, and Operation Ocean Shields are a few examples that have generated geopolitical tensions in Colombia.

Similarly, global financial crisis had generated profound EPU in China. Moreover, the US-China trade war also responsible for the high EPU in China. Besides, the China-India conflicts on territorial issues increased its GPR. Several countries have imposed sanctions related to $\mathrm{CO}_{2}$ emissions on China that created geopolitical tensions. The US, European Union, and Canada also imposed sanctions on China due to the Uighurs issue that have escalated its GPR.

In sum, the social, economic, and geopolitical status of the BRMCC countries motivates us to explore the impact of EPU and GPR on environmental degradation. Based on above backdrop, we propose two hypotheses as follows:

Hypothesis 1 (H1). The investment effect of EPU is greater than the consumption effect, implying that EPU escalates environmental degradation.

Hypothesis 2 (H2). The mitigating effect of GPR is greater than the escalating effect, indicating that GPR impedes environmental degradation.

The present study contributes to the existing body of literature in two dimensions. First, this is the first study to investigate the impact of EPU and GPR on environmental degradation in the BRMCC countries. There is scant knowledge that links both EPU and GPR with environmental degradation. Nevertheless, the limited studies in the prior literature showed contrasting findings. Second, prior studies extensively employed $\mathrm{CO}_{2}$ emissions as an indicator for environmental degradation [11]. However, $\mathrm{CO}_{2}$ emission is just a subset of environmental degradation, and it is unable to capture the complex nature of environmental degradation [21]. To overcome this limitation, ref. [22] proposed ecological footprint $(\mathrm{EF})$ as an indicator for environmental degradation. EF is a comprehensive indicator that captures the environmental degradation in many aspects. It is the area required to reproduce the resources that are being consumed by a country, and to absorb the waste it produces at a given level of technology.

The remainder of this study is ordered as follows: Section 2 reviews the literature related to EF. We present the data in Section 3. Model and methodology are discussed in Section 4. Results are mentioned in Section 5. Discussion on the basis of results is presented in Section 6. Section 7 concludes the study. 


\section{Literature Review}

\subsection{Literature on Determinants of Ecological Footprint}

This section reviews the literature related to determinants of ecological footprint (EF). In addition to this, the current section also reports the literature on the relationship among EPU, GPR, and environment.

There are many studies that probe the validity of environmental Kuznets curve (inverted U-shaped relationship between income and environment). The studies are different from each other on the basis of results, methodologies, and data. Few studies conclude that environmental Kuznets curve does not exist. For instance, one of the studies employ ordinary least squares (OLS) model and weighted least squares (WLS) model on 141 countries to probe the environmental Kuznets curve using EF as an indicator of environmental quality. The findings reveal that environmental Kuznets curve does not hold [23]. Similarly, another study borrows spatial econometric approach to test environmental Kuznets curve. The study also notes that environmental Kuznets curve is not valid for selected countries [24]. Next, a group of researchers re-investigates the validity of environmental Kuznets curve for BRICST countries using FMOLS, DOLS, and AMG approaches. The results conclude that an environmental Kuznets curve is does not exist for BRICST countries. Few studies use time series data to investigate environmental Kuznets curve. For instance, using ARDL approach for Qatar, it is found that environmental Kuznets curve is not valid for Qatar [25].

On the contrary, there exists literature that supports the environmental Kuznets curve. By using the GMM approach, one of the studies investigated the environmental Kuznets curve for high-income, upper-middle, lower-middle, and low-income countries using EF. The results show that environmental Kuznets curve holds for high-income and uppermiddle income countries [26]. Similarly, EKC also exists in 15 MENA countries [27]. Using DOLS and FMOLS approaches, a group of researchers confirms the validity of EKC in the case of BRICS countries [28].

There exists an extensive body of literature that probes the economic and non-economic factors that influence EF. For instance, tourism is one of the determinants of EF. It may either increase or decrease EF. That is, tourists admire improved environment quality that compels policy makers to adopt strict environment measures. As a result EF will be mitigated [29]. On the other hand, tourism can escalate the use of non-renewable energy and pollution intensive goods and services, which escalates EF [30]. Likewise, energy consumption, urbanization, trade, and industrialization are reported key determinants of EF in MENA region [31]. It is also noted that economic globalization increases EF, while social globalization decreases it. Additionally, political globalization does not affect EF in 146 selected countries [32]. Likewise, one of the studies notes that economic growth, energy consumption, urbanization, FDI, and financial development surge EF in 59 Belt and Road countries [33]. Similarly, in OIC countries, trade openness, FDI, and urbanization escalate EF [34]. In one-belt-one road countries, financial development leads to higher EF while globalization impedes it [35]. Similarly, in $16 \mathrm{EU}$ countries, economic growth, energy consumption, renewable energy consumption, and fertility are highlighted as key determinants of EF [36]. One the other hand, urbanization decreases the EF whereas human capital contributes to higher EF in G-7 countries [37]. Parallel to this, another study expounds that economic growth, energy consumption, financial development, urbanization and non-renewable energy consumption increase EF, whereas renewable energy consumption impedes EF [38] Table 1.

\subsection{Literature on the Impact of EPU and GPR on Environmental Degradation}

There exists one-way causality running from EPU to carbon emissions in case of the USA due to the fact that EPU discourages investment in clean energy and turns the attention of policymakers toward economic stability, which effects carbon emissions [7]. Further, it is also concluded that EPU upsurges energy consumption, which increases $\mathrm{CO}_{2}$ emissions in both short- and long-run [57]. Additionally, it is also noted that EPU escalates carbon emissions in both developed and developing countries [6,8]. Regarding the impact 
of provincial level carbon emissions, it is highlighted that EPU of China at provincial level increases the provincial level carbon emissions [58]. Recently, it is documented that EPU also surge $\mathrm{CO}_{2}$ emissions in top ten carbon emitter countries [9]. In the case of the UK, EPU discourages economic growth and energy consumption, and hence $\mathrm{CO}_{2}$ emissions decrease in the short-run [10]. Recently, it is also found that EPU decreases the $\mathrm{CO}_{2}$ emissions in the long-run [11]. Similarly, EPU discourages investment in R\&D and renewable energy, which ultimately mitigates $\mathrm{CO}_{2}$ emissions [12]. Regarding the literature on the relationship between GPR and environmental quality, GPR mitigates renewable energy consumption and investment in R\&D. as a result, GPR leads to environmental degradation [19]. Recently, one of the studies reports that GPR asymmetrically effects carbon emissions in BRICS countries [20].

Table 1. Summary of literature related to determinants of ecological footprint.

\begin{tabular}{|c|c|c|c|}
\hline Reference & Country & Method & Determinants \\
\hline [23] & 141 countries & OLS and WLS & Economic growth \\
\hline [24] & 150 countries & Spatial econometric approach & Economic growth \\
\hline [26] & $\begin{array}{l}\text { High-income, middle-income, } \\
\text { low-income }\end{array}$ & Fixed effect model and GMM model & $\begin{array}{l}\text { Energy consumption, } \\
\text { urbanization, and trade }\end{array}$ \\
\hline [29] & 144 countries & GMM approaches & Tourism \\
\hline$[31]$ & MENA region & FMOLS & $\begin{array}{l}\text { Energy, urbanization, trade, } \\
\text { and political instability }\end{array}$ \\
\hline [25] & Qatar & ARDL methodology & Oil prices and trade \\
\hline [39] & Malaysia & ARDL and Bayer \& Hanck approach & $\begin{array}{c}\text { Economic growth, energy, population, } \\
\text { urbanization, and globalization }\end{array}$ \\
\hline [40] & Pakistan & ARDL approach & Natural resources \\
\hline [27] & 15 MENA countries & Panel co-integration and causality test & $\begin{array}{l}\text { Energy, political institutions, urbanization, } \\
\text { life expectancy, and fertility }\end{array}$ \\
\hline [32] & 146 countries & Extreme bounds analysis & $\begin{array}{l}\text { Economic globalization, social globalization, } \\
\text { and political globalization }\end{array}$ \\
\hline [41] & Pakistan & ARDL approach & $\begin{array}{l}\text { Economic growth, human capital, } \\
\text { and biodiversity }\end{array}$ \\
\hline [42] & Turkey & Bootstrap time-varying causality & Economic growth \\
\hline [43] & India & Bayer and Hanck approach & Human capital \\
\hline$[33]$ & 59 Belt-and-road countries & Driscoll-Kraay approach & $\begin{array}{l}\text { Urbanization, FDI, financial development, } \\
\text { energy, and economic growth }\end{array}$ \\
\hline [28] & BRICS & FMOLS and DOLS & Energy, urbanization, and natural resources \\
\hline [34] & $\mathrm{OIC}$ & DCCE & Trade, FDI, urbanization, institutions \\
\hline [35] & One-belt-one-road countries & PMG-ARDL method & Financial development and globalization \\
\hline [44] & MINT & ARDL approach & $\begin{array}{l}\text { Exports, imports, financial development, } \\
\text { urbanization, (non)renewable energy }\end{array}$ \\
\hline$[21]$ & 11 Newly industrialized countries & AMG methodology & Economic growth \\
\hline [45] & BRICS & FMOLS and DOLS & $\begin{array}{l}\text { Urbanization, natural } \\
\text { resources, renewable energy }\end{array}$ \\
\hline [36] & 16-EU countries & PMG-ARDL method & $\begin{array}{l}\text { Economic growth, energy } \\
\text { consumption, and fertility }\end{array}$ \\
\hline [37] & G7 countries & CUP-FM and CUP-BC methodologies & Human capital and urbanization \\
\hline [38] & MENA & AMG approach & $\begin{array}{l}\text { Economic growth, energy, financial } \\
\text { development, and urbanization }\end{array}$ \\
\hline [30] & 35 Tourism countries & Fixed effect model and GMM model & Inbound and outbound tourism \\
\hline [46] & Turkey & QARDL & Economic growth, (non)renewable energy \\
\hline [47] & Indonesia & Bayer and Hanck approach & $\begin{array}{l}\text { Economic growth, energy, } \\
\text { urbanization, and trade }\end{array}$ \\
\hline [48] & BRICST & FMOLS, DOLS, and AMG approach & Economic growth \\
\hline [49] & US & ARDL approach & $\begin{array}{l}\text { Economic growth, energy, human } \\
\text { capital, and FDI }\end{array}$ \\
\hline [50] & Newly industrialized countries & Second generation panel data methods & FDI \\
\hline [51] & Developing countries & Bayesian model & 22 determinants \\
\hline$[37]$ & China & Bayer and Hanck approach & $\begin{array}{l}\text { Human capital, urbanization, } \\
\text { and natural resources }\end{array}$ \\
\hline [52] & US & ARDL approach & $\begin{array}{c}\text { Economic growth, energy, financial } \\
\text { development, and globalization }\end{array}$ \\
\hline [53] & 16 CEECs & $\begin{array}{l}\text { DSUR, FGLS, GMM, and D-H panel } \\
\text { causality test }\end{array}$ & $\begin{array}{l}\text { economic growth, energy consumption, and } \\
\text { financial development }\end{array}$ \\
\hline [54] & 15 Globalized countries & qantile-on-quantile regression & Globalization \\
\hline [55] & South Asian countries & Panel ARDL & Globalization and technology \\
\hline [56] & Nigeria & NARDL approach & Financial development \\
\hline
\end{tabular}




\section{Data}

The purpose of this study is to probe the determinants of ecological footprint (EF) in five emerging countries (i.e., Brazil, Mexico, Russia, Colombia, and China). We employ annual data from 1995 to 2015 . We selected these countries and time span on the basis of data availability. Data on EF is downloaded from global footprint network (GFN). Next, data on economic policy uncertainty (EPU) (see Baker et al. (2016) [1] for further details on economic policy uncertainty index.) and geopolitical risk (see Caldara and Jacoviello (2018) [59] for further details on geopolitical risk index). GPR data is taken from policyuncertainty.com. On the other hand, data on GDP per capita (GDP), non-renewable energy consumption (EN), renewable energy consumption (REN), and population (POP) is gathered from World Development Indicators (WDI). Table 2 reports the data description.

Table 2. Data description.

\begin{tabular}{cccc}
\hline Abbreviation & Indicator Name & Measurement Scale & Source \\
\hline EF & Ecological footprint & Gha per person & GFN \\
GDP & GDP per capita & GDP per capita (constant 2010\$ US) & WDI \\
EN & Non-renewable energy consumption & Oil equivalent per capita & WDI \\
REN & Renewable energy consumption & Percent of total final energy & WDI \\
POP & Population & Total population & WDI \\
EPU & Economic policy uncertainty index & Number of newspaper articles having & Policyuncertainty.com \\
& & ecertainty related words (e.g., & \\
GPR & Geopolitical risk index & Number of newspaper articles having & Policyuncertainty.com \\
& & geopolitics related words (e.g., & geopolitics, and uncertainty etc.) \\
\hline
\end{tabular}

Note: "GFN" indicates global footprint network while "WDI" represents world development indicators.

We transform all variables into logarithmic form to control heteroscedasticity [60] Further, Table 3 highlights the descriptive statistics of the data.

Table 3. Descriptive Statistics.

\begin{tabular}{cccccccc}
\hline Statistics. & EF & EN & EPU & GDP & GPR & POP & REN \\
\hline Mean & 1.07 & 7.32 & 7.10 & 8.81 & 7.04 & 18.95 & 2.73 \\
Median & 1.07 & 7.31 & 7.09 & 9.04 & 7.04 & 18.78 & 2.87 \\
Maximum & 1.77 & 8.55 & 8.38 & 9.39 & 7.52 & 21.03 & 3.89 \\
Minimum & 0.60 & 6.42 & 5.78 & 7.11 & 6.53 & 17.41 & 1.17 \\
Std. Dev. & 0.33 & 0.64 & 0.48 & 0.54 & 0.18 & 1.11 & 0.90 \\
Skewness & 0.44 & 0.57 & -0.05 & -1.47 & -0.06 & 0.76 & -0.47 \\
Kurtosis & 2.21 & 2.29 & 3.02 & 4.62 & 3.02 & 2.67 & 1.93 \\
Jarque-Bera & $(0.03)^{* *}$ & $(0.01)^{* *}$ & $(0.97)$ & $(0.00)^{* * *}$ & $(0.95)$ & $(0.00)^{* * *}$ & $(0.00)^{* * *}$ \\
\hline Note: (.) indicates the value of probability. ${ }^{* *},{ }^{* * *}$ represent level of significance at 5\%, and 1\% respectively.
\end{tabular}

As can be seen in Table 3, REN has highest standard deviation. It implies that there are large fluctuations in renewable energy series. Next, all series are either positively or negatively skewed. Jarque-Bera test highlights that all variables follow the non-normal distribution except EPU and GPR, which follow the normal distribution.

\section{Model and Methodology}

To investigate the impact of economic policy uncertainty (EPU), geopolitical risk (GPR), and energy consumption on ecological footprint (EF), we employ IPAT approach (influence = population, affluence, and technology) that examines the environmental impacts of human activities [61]:

$$
\mathrm{EF}_{\mathrm{it}}=\beta_{0}+\beta_{1} \mathrm{GDP}_{\mathrm{it}}+\beta_{2} \mathrm{EN}_{\mathrm{it}}+\beta_{3} \mathrm{REN}_{\mathrm{it}}+\beta_{4} \mathrm{POP}_{\mathrm{it}}+\beta_{5} \mathrm{EPU}_{\mathrm{it}}+\beta_{6} \mathrm{GPR}_{\mathrm{it}}+\varepsilon_{\mathrm{it}}
$$


Equation (1) shows the empirical model that we develop for the current study, where $i$ and $t$ represent the cross-section and time, respectively. $\varepsilon_{i t}$ indicates the error term of the model. EF represents ecological footprint. Next, GDP, EN, REN, POP, EPU, and GPR show GDP per capita, non-renewable energy consumption, renewable energy consumption, population, economic policy uncertainty, and geopolitical risk, respectively. In the IPAT model, GDP growth rate is used as a proxy of affluence, population is employed to capture the environmental impact of population growth, and (non)renewable energy is used as a proxy of technology [62]. The prior literature reports that GDP, population and nonrenewable energy often surge environmental degradation [9]. On the contrary, renewable energy plunges the environmental quality [11].

The present study employs fully modified OLS (FMOLS), dynamic OLS (DOLS), augmented mean group (AMG), and Dumitrescu and Hurlin [63] panel Grainger causality approach to explore the relationship among EF, GDP, EN, REN, POP, EPU, and GPR. FMOLS and DOLS estimators investigate the long-run relationship between the variables. Moreover, FMOLS and DOLS use non-parametric and parametric approach respectively to handle the endogeneity and serial correlation. Further, the DOLS approach is relatively better as it produces unbiased and efficient results even in the case of small sample and cross-sectional dependence [41]:

$$
\begin{gathered}
\hat{\beta}_{\mathrm{FMOLS}}=\left[\frac{1}{\mathrm{~N}} \sum_{\mathrm{i}=1}^{\mathrm{N}}\left[\sum_{\mathrm{t}=1}^{\mathrm{T}}\left(\mathrm{X}_{\mathrm{it}}-\overline{\mathrm{X}}_{\mathrm{i}}\right)^{2}\right] \times\left[\left(\sum_{\mathrm{t}=1}^{\mathrm{T}}\left(\mathrm{X}_{\mathrm{it}}-\overline{\mathrm{X}}_{\mathrm{i}}\right) \hat{\mathrm{Y}}_{\mathrm{it}}-\mathrm{T} \hat{\Delta}_{[?] \mu}\right)\right]\right] \\
\hat{\beta}_{\text {DOLS }}=\left[\frac{1}{\mathrm{~N}} \sum_{\mathrm{i}=1}^{\mathrm{N}}\left[\sum_{\mathrm{t}=1}^{\mathrm{T}}\left(\mathrm{X}_{\mathrm{it}} \mathrm{X}_{\mathrm{it}}^{\prime}\right)^{-1}\left(\sum_{\mathrm{t}=1}^{\mathrm{T}} \mathrm{X}_{\mathrm{it}} \hat{\mathrm{Y}}_{\mathrm{it}}\right)\right]\right]
\end{gathered}
$$

Equations (2) and (3) represent the FMOLS and DOLS estimators, where, $X$ and $Y$ are independent and dependent variable(s), respectively. A line of research reports that FMOLS and DOLS may give misleading results if panel sections are correlated [44]. To overcome this limitation, this study also applies augmented mean group estimator (AMG) [64] and [65] which gives efficient results even in case of aforementioned problem. AMG estimator is superior to FMOLS and DOLS as it is applicable even in case of non-stationary data. Thus, it is not necessary to check unit-root and co-integration before employing AMG estimator [21]. AMG consists of two-step procedure that is mentioned as follows.

In first step, we estimate Equation (1) by taking first difference of all the series and incorporating $\mathrm{T}-1$ period dummy:

$$
\Delta \mathrm{EF}_{\mathrm{it}}=\beta_{0}+\beta_{1} \Delta \mathrm{GDP}_{\mathrm{it}}+\beta_{2} \Delta \mathrm{EN}_{\mathrm{it}}+\beta_{3} \Delta \mathrm{REN}_{\mathrm{it}}+\beta_{4} \Delta \mathrm{POP}_{\mathrm{it}}+\beta_{5} \Delta \mathrm{EPU}_{\mathrm{it}}+\beta_{6} \Delta \mathrm{GPR}_{\mathrm{it}}+\sum_{\mathrm{t}=2}^{\mathrm{T}} \rho_{\mathrm{t}}\left(\Delta \mathrm{D}_{\mathrm{t}}\right)+\varepsilon_{\mathrm{it}}
$$

In Equation (4), $\Delta D_{t}$ represents $T-1$ period dummies at first difference. $\rho_{t}$ refer to parameters that show period dummies.

In second step, we transform parameters $\left(\rho_{t}\right)$ in new variable $\left(\tau_{t}\right)$ which shows the common dynamic process. The model is mentioned as follows:

$$
\begin{gathered}
\Delta \mathrm{EF}_{\mathrm{it}}=\beta_{0}+\beta_{1} \Delta \mathrm{GDP}_{\mathrm{it}}+\beta_{2} \Delta \mathrm{EN}_{\mathrm{it}}+\beta_{3} \Delta \mathrm{REN}_{\mathrm{it}}+\beta_{4} \Delta \mathrm{POP}_{\mathrm{it}}+\beta_{5} \Delta \mathrm{EPU}_{\mathrm{it}}+\beta_{6} \Delta \mathrm{GPR}_{\mathrm{it}}+\mathrm{d}_{\mathrm{i}}\left(\tau_{\mathrm{t}}\right)+\varepsilon_{\mathrm{it}} \\
\Delta \mathrm{EF}_{\mathrm{it}}-\tau_{\mathrm{t}}=\beta_{0}+\beta_{1} \Delta \mathrm{GDP}_{\mathrm{it}}+\beta_{2} \Delta \mathrm{EN}_{\mathrm{it}}+\beta_{3} \Delta \mathrm{REN}_{\mathrm{it}}+\beta_{4} \Delta \mathrm{POP}_{\mathrm{it}}+\beta_{5} \Delta \mathrm{EPU}_{\mathrm{it}}+\beta_{6} \Delta \mathrm{GPR}_{\mathrm{it}}+\varepsilon_{\mathrm{it}}
\end{gathered}
$$

The group-specific model is initially altered with $\tau_{t}$ and then the average values of group-specific model parameters are calculated. For instance, the parameter of EPU can be calculated as $\beta_{5}$, AMG $=\frac{1}{\mathrm{~N}} \sum_{\mathrm{i}=1}^{\mathrm{N}} \beta_{5, \mathrm{i}}$. AMG estimator considers the issues of heterogeneity and cross-sectional dependence. Moreover, AMG estimator produces authentic results when there is cross-sectional dependence in heterogeneous panel data [66].

To probe the causality between variables, we also employ Dumitrescu and Hurlin's [63] heterogeneous panel causality test (hereafter D-H test). This test is updated version of 
panel granger causality and gives consistent results even in the presence of cross-sectional dependency [21]. The $\mathrm{D}-\mathrm{H}$ test procedure is given as follows:

$$
\begin{gathered}
\mathrm{W}_{\mathrm{N}, \mathrm{T}}^{\mathrm{HNC}}=\frac{1}{\mathrm{~N}} \sum_{\mathrm{i}=1}^{\mathrm{N}} \mathrm{W}_{\mathrm{i}, \mathrm{t}} \\
\mathrm{Z}_{\mathrm{N}, \mathrm{T}}^{\mathrm{HNC}}=\sqrt{\frac{\mathrm{N}}{2 \mathrm{~K}}}\left(\mathrm{~W}_{\mathrm{N}, \mathrm{T}}^{\mathrm{HNC}}-\mathrm{K}\right), \mathrm{N}(0,1)
\end{gathered}
$$

where, $\mathrm{W}_{\mathrm{i}, \mathrm{t}}$ represents the Wald statistic. However, we can compute $\mathrm{W}_{\mathrm{N}, \mathrm{T}}^{\mathrm{HNC}}$ by averaging each Wald static for cross-sections. The null and alternative hypothesis of D-H test is reported as follows:

Hypothesis 3 (H3). There is no homogenous causality.

Hypothesis 4 (H4). There is homogenous causality.

\section{Empirical Results}

The empirical route employed in the current study is ordered as follows. First, we probe the cross-sectional dependence (CD) in our data to know whether shocks in one country may spillover to other countries as these shocks may produce misleading results (inconsistent parameters) if they are correlated with independent variables [67]. There are many CD tests in literature but the most widely used tests are Breusch-Pagan LM test, Pesaran LM test, and Pesaran CD test. We apply these three CD tests in this study and the results from these CD tests are illustrated in Table 4.

Table 4. Cross-sectional dependence test.

\begin{tabular}{cccc}
\hline Model & Breusch-Pagan LM & Pesaran Scaled LM & Pesaran CD \\
\hline $\begin{array}{c}\text { EF }=\text { f (GDP, EN, REN, } \\
\text { EPU, GPR, POP) }\end{array}$ & $(26.11)[0.00]^{* * *}$ & $(3.60)[0.00]^{* * *}$ & $(2.84)[0.00]^{* * *}$ \\
\hline
\end{tabular}

Note: $\mathrm{H}_{0}$ of all tests is "there is no cross-sectional dependence." (.) and [.] indicate test static and probability values respectively. ${ }^{* * *}$ represents level of significance at $1 \%$.

As can be seen in Table 4 that null hypothesis can be rejected as the probability value is significant at $1 \%$ level of significance. Thus, we report that there is cross-sectional dependence. Second, we employ slope homogeneity test [68]. This test is based on $\hat{\Delta}$ and $\hat{\Delta}_{\text {adj. }}$ values. Results are posted in Table 5 which show that all slopes are heterogeneous except slope of GPR, which is homogenous.

Table 5. Results from homogeneity test.

\begin{tabular}{cccccccc}
\hline Statistics & EF & GDP & EN & REN & POP & EPU & GPR \\
\hline$\hat{\Delta}$ & $14.12^{* * *}$ & $14.28^{* * *}$ & $8.03^{* * *}$ & $2.60^{* * *}$ & $9.09^{* * *}$ & $2.73^{* * *}$ & 0.63 \\
$\hat{\Delta}_{\text {adj. }}$ & $12.05^{* * *}$ & $15.37^{* * *}$ & $8.64^{* * *}$ & $3.25^{* * *}$ & $9.73^{* * *}$ & $2.93^{* * *}$ & 0.60 \\
\hline Note: ${ }^{* * *}$ indicates level of significance at $1 \%$.
\end{tabular}

Third, we discern whether the data have stationary process to restrain from the spurious regression [69]. We use the LLC, IPS, PP-Fisher, and CIPS unit root tests for this purpose. It is worth mentioning that the CIPS unit root test [70] handles the issues of heterogeneity and cross-sectional dependence. Thus, the CIPS unit root test is relatively superior as compare to the LLC, IPS, and PP-Fisher tests. We present the unit root results in Table 6.

Table 6 illustrates the results from unit root tests. The findings from all unit root tests reveal that the null hypothesis of no unit root cannot be rejected at level. On the contrary, null hypothesis can be rejected at first difference. It implies that all variables are integrated at I (1). 
Table 6. Unit root tests.

\begin{tabular}{|c|c|c|c|c|c|c|c|c|}
\hline \multirow[t]{2}{*}{ Variable } & \multicolumn{4}{|c|}{ Level } & \multicolumn{4}{|c|}{ First Difference } \\
\hline & LLC & IPS & PP-Fisher & CIPS & LLC & IPS & PP-Fisher & CIPS \\
\hline $\mathrm{EF}$ & $(0.36)$ & $(0.17)$ & $(0.00)^{* * *}$ & -0.19 & $(0.09) *$ & $(0.00)^{* * *}$ & $(0.00)^{* * *}$ & $-2.70^{* * *}$ \\
\hline EN & $(0.95)$ & (0.90) & $(0.00)^{* * *}$ & -0.90 & $(0.00)^{* * *}$ & $(0.00)^{* * *}$ & $(0.00)^{* * *}$ & $-3.57^{* * *}$ \\
\hline EPU & $(0.92)$ & $(0.84)$ & $(0.81)$ & -0.95 & $(0.00)^{* * *}$ & $(0.00)^{* * *}$ & $(0.00)^{* * *}$ & $-3.21^{* * *}$ \\
\hline GDP & $(1.00)$ & (1.00) & $(0.02)^{* *}$ & -0.96 & $(0.00)^{* * *}$ & $(0.00)^{* * *}$ & $(0.00)^{* * *}$ & $-2.98^{* * *}$ \\
\hline GPR & $(0.21)$ & $(0.14)$ & $(0.08) *$ & -0.19 & $(0.00)^{* * *}$ & $(0.00)^{* * *}$ & $(0.00)^{* * *}$ & $-2.66^{* * *}$ \\
\hline POP & (1.00) & $(0.00)^{* *}$ & $(0.00)^{* *}$ & -1.32 & $(0.00)^{* * *}$ & $(0.00)^{* * *}$ & $(0.00)^{* * *}$ & $-2.83^{* * * *}$ \\
\hline REN & $(0.25)$ & $(0.41)$ & $(0.00)^{* * *}$ & -0.17 & $(0.00)^{* * *}$ & $(0.00)^{* * *}$ & $(0.00)^{* * *}$ & $-2.65^{* * *}$ \\
\hline
\end{tabular}

Note: (.) represents the probability value. ${ }^{*}, * * * * *$ indicate level of significance at $10 \%, 5 \%$, and $1 \%$ respectively. The critical value of CIPS unit root test at $1 \%$ level of significance is -2.57 .

Fourth, as the variables are stationary at first difference therefore we check whether the linear combination of these variables is stationary. If the linear combination of these variables is stationary, this implies that co-integration does exist. To probe the co-integration among the variables we employ Kao co-integration test. However, this test may give misleading results in the presence of heterogeneity and cross-sectional dependence. To resolve this limitation, we also apply Westerlund co-integration test which is consistent even if there is heterogeneity and cross-sectional dependence [41]. The results from the Kao test and Westerlund test are posted in Table 7.

Table 7. Co-integration results.

\begin{tabular}{ccc}
\hline Test & Statistic & Probability \\
\hline Kao test & -3.99 & $0.00^{* * *}$ \\
\hline Westerlund (2007) [71] & & \\
$\mathrm{P}_{\mathrm{t}}$ & -3.54 & $0.00^{* * *}$ \\
$\mathrm{P}_{\mathrm{a}}$ & -4.76 & $0.00^{* * *}$ \\
$\mathrm{G}_{\mathrm{t}}$ & -4.23 & $0.00^{* * *}$ \\
$\mathrm{G}_{\mathrm{a}}$ & -5.98 & $0.00^{* * *}$
\end{tabular}

Note: ${ }^{* * *}$ indicates level of significance at 1\%. The null hypothesis of Kao test and Westerlund (2007) assumes no cointegration.

Table 7 shows the results from co-integration tests. The null hypothesis of no cointegration can be rejected as the probability values are significant at $1 \%$ level of significance. Thus, we conclude that co-integration (long-run relationships) exists among the variables. Fifth, we employ FMOLS, DOLS, and AMG estimators to probe the long-run relationship among variables. Table 8 reports the results from FMOLS, DOLS, AMG estimators.

Findings from FMOLS highlight that all the coefficients are statistically significant at a $1 \%$ level of significance. In detail, the coefficient of GDP is 0.31 , which means that a $1 \%$ increase in GDP escalates the EF by $0.31 \%$, thus implying that improvement in income level increases the ecological footprint of the panel of the emerging countries. These findings are in line with the findings of previous literature [41]. In addition, the coefficient of EN is 0.30, which translate that the EN increases the EF by $0.30 \%$ when EN increases by a $1 \%$. There are several studies who report the similar findings [41]. For the renewable energy, the coefficient of REN is -0.32 , thus, this posited that renewable energy consumption rather reduced pressure on the ecological footprint through a reduction in human ecological needs. This evidence is consistent with the previous studies [46]. Likewise, the coefficient of POP is 0.0 which shows that there is meagre or no effect of population on EF. However, the coefficient of EPU is 0.28 , which concludes that an increase of $0.28 \%$ in EF is fostered by a $1 \%$ increase in EPU. Moreover, the coefficient of GPR is -0.29 , which reports that $1 \%$ increase in GPR decreases the EF by $0.29 \%$. 
Table 8. Results from FMOLS, DOLS, and AMG estimators.

\begin{tabular}{cccc}
\hline Variable & FMOLS & DOLS & AMG \\
\hline GDP & 0.31 & 0.19 & 0.32 \\
& $(0.00)^{* * *}$ & $(0.00)^{* * *}$ & $(0.00)^{* * *}$ \\
EN & 0.30 & 0.19 & 0.10 \\
REN & $(0.00)^{* * *}$ & $(0.00)^{* * *}$ & $(0.00)^{* * *}$ \\
POP & -0.32 & -0.23 & -0.24 \\
& $(0.00)^{* * *}$ & $(0.00)^{* * *}$ & $(0.00)^{* * *}$ \\
EPU & 0.13 & 0.15 & -0.75 \\
& $(0.00)^{* * *}$ & $(0.00)^{* * *}$ & $(0.13)$ \\
GPR & 0.28 & 0.04 & 0.10 \\
& $(0.00)^{* * *}$ & $(0.00)^{* * *}$ & $(0.00)^{* * *}$ \\
& -0.29 & -0.11 & -0.18 \\
& $(0.00)^{* * *}$ & $(0.00)^{* * *}$ & $(0.00)^{* * *}$ \\
\hline
\end{tabular}

Note: (.) represents probability value. ${ }^{* * *}$ indicate the level of significance at $1 \%$.

Similarly, the results from DOLS conclude that all coefficients are statistically significant at $1 \%$ level of significance. In detail, GDP, EN, and POP escalate EF. On the contrary, REN decreases the EF. Further, the coefficient of EPU depicts that EPU increases the EF. On the other hand, the coefficient of GPR is negative, therefore, it could be concluded that GPR mitigates the EF.

Findings from the AMG estimator report that all coefficients are statistically significant except POP, which is statistically insignificant. Results from the AMG estimator also reveal that GDP and EN increase the EF. Further, REN plunges the EF, which is the same result from the previously expressed estimators. Next, the coefficient of EPU is 0.10 which shows that an increase in the level of uncertainty regarding the economic policy of the examined panel countries is responsible for more hazardous environmental damage. There are few possible reasons behind this result. For instance, EPU discourages innovations, R\&D, and technology, which in turn increase environmental degradation. A similar finding has been reported in the case of the USA [7]. The coefficient of GPR depicts that a decrease of $0.18 \%$ in the EF is fostered by a $1 \%$ increase in the GPR. The same findings have been presented in case of top resource rich countries [8]. There are also few possible reasons behind these results. For instance, an increase in the GPR is responsible for a declining economic growth, which in turn mitigates the EF. This is because, rising political instability, civil unrest, and amid other states' and regional tensions is detrimental to sustainable economic growth. Additionally, GPR also reduces FPI, trade, and investment, which in turn reduces the environmental degradation (EF).

Since the FMOLS, DOLS, AMG estimators just report the long-run relationship, and do not explain the causality therefore we employ D-H causality test. As mentioned earlier, the $\mathrm{D}-\mathrm{H}$ test produces consistent results in the presence of cross-sectional heterogeneity therefore it is being widely employed in recent studies [41]. Table 9 illustrates the results from the D-H test.

The findings from the $\mathrm{D}-\mathrm{H}$ causality test reveal that bi-directional causality exists between GDP and EF, POP and EF, GDP and EN, POP and EN, REN and EN, GDP and EPU, POP and EPU, POP and GDP, and between REN and GDP. Based on these results, we report the following explanations:

- The two-way causality between GDP and EF indicates that GDP causes EF and viceversa. More specifically, any attempt to boost GDP will increase the environmental degradation. On the other hand, the rise in environmental degradation affects the economic growth as well. These findings are in line with [62].

- The bi-directional causality between GDP and EN concludes that rise in non-renewable energy consumption leads to higher economic growth. Moreover, any attempt to increase GDP growth will escalate the non-renewable energy consumption as well. This conclusion is similar to [72]. 
- The two-way causality between REN and GDP implies that increase in renewable energy contributes to GDP growth, while rise in income encourages the use of renewable energy in these countries. This outcome is backed by [73].

Table 9. Results from D-H causality test.

\begin{tabular}{cccc}
\hline Null Hypothesis: & W-Stat. & Z Bar-Stat. & Prob. \\
\hline EN $<\neq>$ EF & 6.03423 & 6.26138 & $0.00^{* * *}$ \\
EF $<\neq>$ EN & 1.72193 & 0.76134 & 0.44 \\
EPU $<\neq>$ EF & 1.03408 & -0.11596 & 0.90 \\
EF $<\neq>$ EPU & 3.65599 & 3.22810 & $0.00^{* * *}$ \\
GDP $<\neq>$ EF & 4.35470 & 4.11926 & $0.00^{* * *}$ \\
EF $<\neq>$ GDP & 58.8704 & 73.6503 & $0.00^{* * *}$ \\
GPR $<\neq>$ EF & 1.31879 & 0.24717 & 0.80 \\
EF $<\neq>$ GPR & 0.96907 & -0.19888 & 0.84 \\
POP $<\neq>$ EF & 7.80364 & 8.51815 & $0.00^{* * *}$ \\
EF $<\neq>$ POP & 46.8138 & 58.2729 & $0.00^{* * *}$ \\
REN $<\neq>$ EF & 1.48405 & 0.45794 & 0.64 \\
EF $<\neq>$ REN & 3.38019 & 2.87634 & $0.00^{* * *}$ \\
\hline
\end{tabular}

Note: null hypothesis of D-H causality test assumes there is no causal relationship. ${ }^{* * *}$ indicate level of significance at $1 \%$. Moreover, detailed results from $\mathrm{D}-\mathrm{H}$ causality test will be available upon request.

\section{Discussion}

In this section, we briefly explain the results with their practical implications. The findings from FMOLS, DOLS, and AMG estimators reveal that GDP and EN escalates environmental degradation in the BRMCC countries. This infers that economic growth achieved by non-renewable energy consumption deteriorates environmental quality. These findings are in line with recent studies [74-76]. These countries consumed a very high share of non-renewable energy in their total energy consumption. They attained high economic growth at a cost of environmental degradation. On the other hand, REN plunges EF. The findings are backed by $[11,44,77]$. Some developed economies (e.g., Denmark, Austria, Switzerland, and Finland) expanded the use of renewables and had profoundly impeded environmental degradation. Hence, the BRMCC countries should also enlarge their renewable energy consumption. Incentives can be given to promote renewable energy consumption in order to achieve sustainable economic development.

Next, EPU is responsible for rising EF. This validates our first hypothesis that the consumption effect is greater than the investment effect. The result is consistent with [6-9]. Hence, the policy makers should mitigate the policies that related to uncertainty because they have both economic and environmental impacts. On the contrary, GPR plunges EF which accomplishes that the BRMCC countries can reduce EF at the cost of GPR. This validates the second hypothesis that the mitigating effect is stronger than the escalating effect. These findings are backed by $[8,20]$. GPR discourages economic growth and energy consumption, consequently it plunges environmental degradation. Therefore, the policy makers should be caution of using GPR as a tool to mitigate EF because it has negative economic and social effects.

Last but not least, the D-H causality test reports a two-way causality between GDP and EF which is consistent with [41]. This supports the feedback hypothesis and the policy makers should control EPU to achieve economic growth. Likewise, REN and GDP have a bi-directional causal relationship which implies that using REN is a way to achieve pollution free environment without losing economic growth (decoupling). Similar findings are observed by [44].

\section{Conclusions}

Since the turn of 21st century, the world is experiencing episodes of high economic policy uncertainty (EPU) and geopolitical risk (GPR). These two factors not only affect the socioeconomic indicators, but also the environmental quality. On this basis, the purpose of 
this study is to investigate the impact of EPU, GPR, and energy consumption on ecological footprint (EF) in the BRMCC countries. In order to estimate the long-run relationships, we employ FMOLS, DOLS, and AMG estimators. We also use the D-H causality test to probe the causality between the variables.

The study finds that EPU escalates EF. This implies that EPU leads to environmental degradation in these countries. On the contrary, our study also finds that GPR decreases EF. This indicates that GPR ameliorates the environmental quality in the BRMCC countries. The findings also reveal that non-renewable energy escalates EF, whereas renewable energy decreases it. The implication of these findings is that while non-renewable energy deteriorates environmental quality; renewable energy upsurges environmental quality. Nevertheless, the D-H causality test concludes that there is bidirectional causality between GDP and EF, and between renewable energy and GDP. This expounds that economic growth is responsible for environmental degradation. On the other hand, environmental degradation affects the GDP as well. In addition, GDP causes renewable energy consumption and vice-versa.

Given these findings, related policies are put forward. First, policy makers should take measures to mitigate the EPU because EPU is responsible for environmental degradation. International organizations such as World Bank and IMF should guide the emerging countries to devise appropriate economic policies. In this regards, international conferences, summits, and trainings can be held. Second, the economic policies should be announced and implemented for a longer time span to impede the uncertainty. Moreover, the economic policies should be publicly announced, and should not have any associated implicit information.

Although GPR is a significant factor that mitigates environmental degradation, it cannot be used as an effective tool in controlling environmental degradation. Nonetheless, a strong economic policy could adequately serve as a cushion to balance the potential negative effects of GPR during periods of political instability and regional tensions. Furthermore, policy makers should put forward some alternatives on innovations and technological advancements that can help to improve environmental quality without poising adverse effect on GPR. In addition, these economies should further intensify their energy transition programs. This implies that, renewable energy utilization should be further promoted. As renewable energy leads to sustainable economic growth, policy makers should encourage its usage by giving subsidy to renewable products. Research grants for renewable energy should be awarded. Investment in renewable energy should be encouraged by rendering subsidized loans. Public awareness programs could be launched to encourage people to use renewables.

There are a few limitations of this study. First, a small data sample with respect to country and time period was used due to unavailability of more data. Moreover, due to the small dataset, several control variables are not added in the models, which may lead to issues of omitted variable bias. A for future research directions, researchers may consider the world uncertainty index as a proxy of EPU. Moreover, quantile-based estimation techniques could be used to present more comprehensive findings on the relationship between EPU, GPR, and EF. Finally, asymmetric modelling could also be employed to explore the positive and negative shocks of EPU and GPR on environmental degradation.

Author Contributions: M.K.A. Conceptualization; Q.R.S. Data curation, Formal analysis; H.H.L. Supervision; M.K.A. and A.A.A. Writing-original draft; H.H.L. and M.A. Writing-review \& editing. All authors have read and agreed to the published version of the manuscript.

Funding: This research received no external funding.

Institutional Review Board Statement: Not Applicable.

Informed Consent Statement: Not Applicable.

Data Availability Statement: Data will be made available upon request.

Acknowledgments: Authors acknowledge the Editorial Team and Reviewers.

Conflicts of Interest: The authors declare no conflict of interest. 


\section{References}

1. Baker, S.R.; Bloom, N.; Davis, S.J. Measuring economic policy uncertainty. Q. J. Econ. 2016, 131, 1593-1636. [CrossRef]

2. Sahinoz, S.; Erdogan, C.E. Economic policy uncertainty and economic activity in Turkey. Appl. Econ. Lett. 2018, 25, 1517-1520. [CrossRef]

3. Kang, W.; Ratti, R.A. Oil shocks, policy uncertainty and stock market return. J. Int. Financ. Mark. Inst. Money 2013, 26, 305-318. [CrossRef]

4. Rehman, M.U.; Apergis, N. Sensitivity of economic policy uncertainty to investor sentiment. Stud. Econ. Financ. 2019, 36, 114-129. [CrossRef]

5. Kang, W.; Lee, K.; Ratti, R.A. Economic policy uncertainty and firm-level investment. J. Macroecon. 2014, 39, 42-53. [CrossRef]

6. Wang, Q.; Xiao, K.; Lu, Z. Does Economic Policy Uncertainty Affect $\mathrm{CO}_{2}$ Emissions? Empirical Evidence from the United States. Sustainability 2020, 12, 9108. [CrossRef]

7. Jiang, Y.; Zhou, Z.; Liu, C. Does economic policy uncertainty matter for carbon emission? Evidence from US sector level data. Environ. Sci. Pollut. Res. 2019, 26, 24380-24394. [CrossRef]

8. Adams, S.; Adedoyin, F.; Olaniran, E.; Bekun, F.V. Energy consumption, economic policy uncertainty and carbon emissions; causality evidence from resource rich economies. Econ. Anal. Policy 2020, 68, 179-190. [CrossRef]

9. Anser, M.K.; Apergis, N.; Syed, Q.R. Impact of economic policy uncertainty on $\mathrm{CO}_{2}$ emissions: Evidence from top ten carbon emitter countries. Environ. Sci. Pollut. Res. 2021, 1-10. [CrossRef]

10. Adedoyin, F.F.; Zakari, A. Energy consumption, economic expansion, and $\mathrm{CO}_{2}$ emission in the UK: The role of economic policy uncertainty. Sci. Total Environ. 2020, 738, 140014. [CrossRef]

11. Syed, Q.R.; Bouri, E. Impact of economic policy uncertainty on $\mathrm{CO}_{2}$ emissions in the US: Evidence from bootstrap ARDL approach. J. Public Aff. 2021, e2595. [CrossRef]

12. Chen, Y.; Shen, X.; Wang, L. The Heterogeneity Research of the Impact of EPU on Environmental Pollution: Empirical Evidence Based on 15 Countries. Sustainability 2021, 13, 4166. [CrossRef]

13. Abbasi, K.R.; Adedoyin, F.F. Do energy use and economic policy uncertainty affect $\mathrm{CO}_{2}$ emissions in China? Empirical evidence from the dynamic ARDL simulation approach. Environ. Sci. Pollut. Res. 2021, 1-13. [CrossRef]

14. Akadiri, S.S.; Eluwole, K.K.; Akadiri, A.C.; Avci, T. Does causality between geopolitical risk, tourism and economic growth matter? Evidence from Turkey. J. Hosp. Tour. Manag. 2020, 43, 273-277. [CrossRef]

15. Rasoulinezhad, E.; Taghizadeh, H.F.; Sung, J.; Panthamit, N. Geopolitical risk and energy transition in Russia: Evidence from ARDL bounds testing method. Sustainability 2020, 12, 2689. [CrossRef]

16. Su, C.W.; Khan, K.; Tao, R.; Nicoleta, C.M. Does geopolitical risk strengthen or depress oil prices and financial liquidity? Evidence from Saudi Arabia. Energy 2019, 187, 116003. [CrossRef]

17. Pan, W.F. Geopolitical Risk and R\&D investment. SSRN 2019, 3258111. [CrossRef]

18. Wang, X.; Wu, Y.; Xu, W. Geopolitical risk and investment. SSRN 2019, 3305739. [CrossRef]

19. Anser, M.K.; Syed, Q.R.; Apergis, N. Does geopolitical risk escalate $\mathrm{CO}_{2}$ emissions? Evidence from the BRICS countries. Environ. Sci. Pollut. Res. 2021, 1-11. [CrossRef]

20. Zhao, W.; Zhong, R.; Sohail, S.; Majeed, M.T.; Ullah, S. Geopolitical risks, energy consumption, and CO 2 emissions in BRICS: An asymmetric analysis. Environ. Sci. Pollut. Res. 2021, 1-12. [CrossRef]

21. Destek, M.A.; Sarkodie, S.A. Investigation of environmental Kuznets curve for ecological footprint: The role of energy and financial development. Sci. Total Environ. 2019, 650, 2483-2489. [CrossRef]

22. Rees, W.E. Ecological footprints and appropriated carrying capacity: What urban economics leaves out. Environ. Urban. 1992, 4, 121-130. [CrossRef]

23. Bagliani, M.; Bravo, G.; Dalmazzone, S. A consumption-based approach to environmental Kuznets curves using the ecological footprint indicator. Ecol. Econ. 2008, 65, 650-661. [CrossRef]

24. Wang, Y.; Kang, L.; Wu, X.; Xiao, Y. Estimating the environmental Kuznets curve for ecological footprint at the global level: A spatial econometric approach. Ecol. Indic. 2013, 34, 15-21. [CrossRef]

25. Mrabet, Z.; Al-Samara, M.; Jarallah, S.H. The impact of economic development on environmental degradation in Qatar. Environ. Ecol. Stati. 2017, 24, 7-38. [CrossRef]

26. Al-Mulali, U.; Weng, W.C.; Sheau, T.L.; Mohammed, A.H. Investigating the environmental Kuznets curve (EKC) hypothesis by utilizing the ecological footprint as an indicator of environmental degradation. Ecol. Indic. 2015, 48, 315-323. [CrossRef]

27. Charfeddine, L.; Mrabet, Z. The impact of economic development and social-political factors on ecological footprint: A panel data analysis for 15 MENA countries. Renew. Sustain. Energy Rev. 2017, 76, 138-154. [CrossRef]

28. Danish, U.R.; Khan, S.U.D. Determinants of the ecological footprint: Role of renewable energy, natural resources, and urbanization. Sustain. Cities Soc. 2020, 54, 101996. [CrossRef]

29. Ozturk, I.; Al-Mulali, U.; Saboori, B. Investigating the environmental Kuznets curve hypothesis: The role of tourism and ecological footprint. Environ. Sci. Pollut. Res. 2016, 23, 1916-1928. [CrossRef]

30. Qureshi, M.I.; Elashkar, E.E.; Shoukry, A.M.; Aamir, A.; Mahmood, N.H.N.; Rasli, A.M.; Zaman, K. Measuring the ecological footprint of inbound and outbound tourists: Evidence from a panel of 35 countries. Clean. Technol. Environ. Policy 2019, 21, 1949-1967. [CrossRef]

31. Al-Mulali, U.; Ozturk, I. The effect of energy consumption, urbanization, trade openness, industrial output, and the political stability on the environmental degradation in the MENA (Middle East and North African) region. Energy 2015, 84, 382-389. [CrossRef]

32. Rudolph, A.; Figge, L. Determinants of Ecological Footprints: What is the role of globalization? Ecol. Indic. 2017, 81, 348-361. [CrossRef] 
33. Baloch, M.A.; Zhang, J.; Iqbal, K.; Iqbal, Z. The effect of financial development on ecological footprint in BRI countries: Evidence from panel data estimation. Environ. Sci. Pollut. Res. 2019, 26, 6199-6208. [CrossRef] [PubMed]

34. Ali, S.; Yusop, Z.; Kaliappan, S.R.; Chin, L. Dynamic common correlated effects of trade openness, FDI, and institutional performance on environmental quality: Evidence from OIC countries. Environ. Sci. Pollut. Res. 2020, 1-12. [CrossRef] [PubMed]

35. Saud, S.; Chen, S.; Haseeb, A. The role of financial development and globalization in the environment: Accounting ecological footprint indicators for selected one-belt-one-road initiative countries. J. Clean. Prod. 2020, 250, 119518. [CrossRef]

36. Alola, A.A.; Bekun, F.V.; Sarkodie, S.A. Dynamic impact of trade policy, economic growth, fertility rate, renewable and nonrenewable energy consumption on ecological footprint in Europe. Sci. Total Environ. 2019, 685, 702-709. [CrossRef]

37. Ahmed, Z.; Asghar, M.M.; Malik, M.N.; Nawaz, K. Moving towards a sustainable environment: The dynamic linkage between natural resources, human capital, urbanization, economic growth, and ecological footprint in China. Res. Policy 2020, 67, 101677. [CrossRef]

38. Nathaniel, S.; Anyanwu, O.; Shah, M. Renewable energy, urbanization, and ecological footprint in the Middle East and North Africa region. Environ. Sci. Pollut. Res. 2020, 1-13. [CrossRef]

39. Ahmed, Z.; Wang, Z.; Mahmood, F.; Hafeez, M.; Ali, N. Does globalization increase the ecological footprint? Empirical evidence from Malaysia. Environ. Sci. Pollut. Res. 2019, 26, 18565-18582. [CrossRef]

40. Hassan, S.T.; Xia, E.; Khan, N.H.; Shah, S.M.A. Economic growth, natural resources, and ecological footprints: Evidence from Pakistan. Environ. Sci. Pollut. Res. 2019, 26, 2929-2938. [CrossRef]

41. Danish, H.S.T.; Baloch, M.A.; Mahmood, N.; Zhang, J. Linking economic growth and ecological footprint through human capital and biocapacity. Sustain. Cities Soc. 2019, 47, 101516. [CrossRef]

42. Ozcan, B.; Apergis, N.; Shahbaz, M. A revisit of the environmental Kuznets curve hypothesis for Turkey: New evidence from bootstrap rolling window causality. Environ. Sci. Pollut. Res. 2018, 25, 32381-32394. [CrossRef] [PubMed]

43. Ahmed, Z.; Wang, Z. Investigating the impact of human capital on the ecological footprint in India: An empirical analysis. Environ. Sci. Pollut. Res. 2019, 26, 26782-26796. [CrossRef]

44. Dogan, E.; Ulucak, R.; Kocak, E.; Isik, C. The use of ecological footprint in estimating the environmental Kuznets curve hypothesis for BRICST by considering cross-section dependence and heterogeneity. Sci. Total Environ. 2020, 723, 138063. [CrossRef] [PubMed]

45. Ahmed, Z.; Zafar, M.W.; Ali, S. Linking urbanization, human capital, and the ecological footprint in G7 countries: An empirical analysis. Sustain. Cities Soc. 2020, 55, 102064. [CrossRef]

46. Sharif, A.; Baris, T.O.; Uzuner, G.; Ozturk, I.; Sinha, A. Revisiting the role of renewable and non-renewable energy consumption on Turkey's ecological footprint: Evidence from Quantile ARDL approach. Sustain. Cities Soc. 2020, 102138. [CrossRef]

47. Nathaniel, S.P. Ecological footprint, energy use, trade, and urbanization linkage in Indonesia. Geo. J. 2020, 1-14. [CrossRef]

48. Dogan, E.; Taspinar, N.; Gokmenoglu, K.K. Determinants of ecological footprint in MINT countries. Energy Environ. 2020, 30, 1065-1086. [CrossRef]

49. Zafar, M.W.; Mirza, F.M.; Zaidi, S.A.H.; Hou, F. The nexus of renewable and nonrenewable energy consumption, trade openness, and $\mathrm{CO}_{2}$ emissions in the framework of EKC: Evidence from emerging economies. Environ. Sci. Pollut. Res. 2019, 26, 15162-15173. [CrossRef]

50. Destek, M.A.; Okumus, I. Does pollution haven hypothesis hold in newly industrialized countries? Evidence from ecological footprint. Environ. Sci. Pollut. Res. 2019, 26, 23689-23695. [CrossRef]

51. Fakher, H.A. Investigating the determinant factors of environmental quality (based on ecological carbon footprint index). Environ. Sci. Pollut. Res. 2019, 26, 10276-10291. [CrossRef] [PubMed]

52. Usman, O.; Akadiri, S.S.; Adeshola, I. Role of renewable energy and globalization on ecological footprint in the USA: Implications for environmental sustainability. Environ. Sci. Pollut. Res. 2020, 1-13. [CrossRef] [PubMed]

53. Shujah, U.R.; Chen, S.; Saud, S.; Saleem, N.; Bari, M.W. Nexus between financial development, energy consumption, income level, and ecological footprint in CEE countries: Do human capital and biocapacity matter? Environ. Sci. Pollut. Res. 2019, 26, 31856-31872. [CrossRef] [PubMed]

54. Sharif, A.; Afshan, S.; Qureshi, M.A. Idolization and ramification between globalization and ecological footprints: Evidence from quantile-on-quantile approach. Environ. Sci. Pollut. Res. 2019, 26, 11191-11211. [CrossRef]

55. Sabir, S.; Gorus, M.S. The impact of globalization on ecological footprint: Empirical evidence from the South Asian countries. Environ. Sci. Pollut. Res. 2019, 26, 33387-33398. [CrossRef]

56. Omoke, P.C.; Nwani, C.; Effiong, E.L.; Evbuomwan, O.O.; Emenekwe, C.C. The impact of financial development on carbon, non-carbon, and total ecological footprint in Nigeria: New evidence from asymmetric dynamic analysis. Environ. Sci. Pollut. Res. 2020, 27, 21628-21646. [CrossRef]

57. Danish, U.R.; Khan, S.U.D. Relationship between energy intensity and $\mathrm{CO}_{2}$ emissions: Does economic policy matter? Sustain. Dev. 2020, 28, 1457-1464. [CrossRef]

58. Yu, J.; Shi, X.; Guo, D.; Yang, L. Economic policy uncertainty (EPU) and firm carbon emissions: Evidence using a China provincial EPU index. Energy Econ. 2021, 94, 105071. [CrossRef]

59. Caldara, D.; Iacoviello, M. Measuring geopolitical risk. FRB Int. Financ. Discuss. Pap. 2018, 1222, 1-66. [CrossRef]

60. Farhani, S.; Shahbaz, M.; Arouri, M.E.H. Panel analysis of $\mathrm{CO}_{2}$ emissions, GDP, energy consumption, trade openness and urbanization for MENA countries. MPRA Pap. 2013, 1-20. Available online: https://mpra.ub.uni-muenchen.de/id/eprint/49258 (accessed on 22 May 2021).

61. Ehrlich, P.R.; Holdren, J.P. Impact of population growth. Science 1971, 171, 1212-1217. [CrossRef] [PubMed] 
62. Anser, M.K.; Apergis, N.; Syed, Q.R.; Alola, A.A. Exploring a new perspective of sustainable development drive through environmental Phillips curve in the case of the BRICST countries. Environ. Sci. Pollut. Res. 2021, 1-11. [CrossRef]

63. Dumitrescu, E.I.; Hurlin, C. Testing for Granger non-causality in heterogeneous panels. Econ. Modell. 2012, 29, 1450-1460. [CrossRef]

64. Eberhardt, M.; Teal, F. Productivity Analysis in Global Manufacturing Production. Dep. Econ. Discuss. Pap. Ser. 2010. Available online: https:/ / ora.ox.ac.uk/objects/uuid:ea831625-9014-40ec-abc5-516ecfbd2118 (accessed on 22 May 2021).

65. Bond, S.; Eberhardt, M. Accounting for Unobserved Heterogeneity in Panel Time Series Models; University of Oxford: Oxford, UK, 2013.

66. Baltagi, B.H. The Oxford Handbook of Panel Data; Baltagi, B.H., Ed.; Oxford University Press: Oxford, UK, 2015. [CrossRef]

67. Pesaran, M.H. Time Series and Panel Data Econometrics, 1st ed.; Oxford University Press: Oxford, UK, 2015.

68. Pesaran, M.H.; Yamagata, T. Testing slope homogeneity in large panels. J. Econ. 2008, 142, 50-93. [CrossRef]

69. Ulucak, R.; Bilgili, F. A reinvestigation of EKC model by ecological footprint measurement for high, middle and low income countries. J. Clean. Prod. 2018, 188, 144-157. [CrossRef]

70. Pesaran, M.H. A simple panel unit root test in the presence of cross sectional dependence. J. Appl. Econ. 2007, 22, 265-312. [CrossRef]

71. Westerlund, J. Testing for error correction in panel data. Oxf. Bull. Econ. Statis. 2007, 69, 709-748. [CrossRef]

72. Lee, C.C. Energy consumption and GDP in developing countries: A cointegrated panel analysis. Energy Econ. 2005, 27, 415-427. [CrossRef]

73. Cai, Y.; Sam, C.Y.; Chang, T. Nexus between clean energy consumption, economic growth and $\mathrm{CO}_{2}$ emissions. J. Clean. Prod. 2018, 182, 1001-1011. [CrossRef]

74. Adedoyin, F.F.; Alola, A.A.; Bekun, F.V. An assessment of environmental sustainability corridor: The role of economic expansion and research and development in EU countries. Sci. Total Environ. 2020, 713, 136726. [CrossRef] [PubMed]

75. Asongu, S.A.; Agboola, M.O.; Alola, A.A.; Bekun, F.V. The criticality of growth, urbanization, electricity and fossil fuel consumption to environment sustainability in Africa. Sci. Total Environ. 2020, 712, 136376. [CrossRef] [PubMed]

76. Gyamfi, B.A.; Adedoyin, F.F.; Bein, M.A.; Bekun, F.V.; Agozie, D.Q. The anthropogenic consequences of energy consumption in E7 economies: Juxtaposing roles of renewable, coal, nuclear, oil and gas energy: Evidence from panel quantile method. J. Clean. Prod. 2021, 295, 126373. [CrossRef]

77. Onifade, S.T.; Erdoğan, S.; Alagöz, M.; Bekun, F.V. Renewables as a pathway to environmental sustainability targets in the era of trade liberalization: Empirical evidence from Turkey and the Caspian countries. Environ. Sci. Pollut. Res. 2021, 1-12. [CrossRef] 